\title{
Comparison of Three Prosthodontic Treatment Modalities for Patients with Periodontally Compromised Anterior Mandibular Teeth: A 2-year follow-up study
}

\section{Usporedba triju vrsta protetičke terapije za pacijente s parodontno kompromitiranim prednjim zubima u mandibuli: dvogodišnje praćenje}

\author{
${ }^{1}$ Department of Prosthodontics, School of Dental Medicine \& Clinical Hospital Centre Zagreb, University of Zagreb, Zagreb, Croatia \\ Zavod za mobilnu protetiku Stomatološkog fakulteta u Zagrebu i Klinički bolnički centar Zagreb, Hrvatska \\ 2 Department of Prosthodontics, School of Dental Medicine, University of Zagreb, Zagreb, Croatia \\ Zavod za mobilnu protetiku Stomatološkog fakulteta u Zagrebu, Hrvatska \\ 3 Private Dental Office, Zagreb, Croatia \\ Privatna stomatološka ordinacija, Zagreb, Hrvatska \\ ${ }^{4}$ Department of Prosthodontics, Division of Dental Medicine, Faculty of Medicine, University of Ljubljana \& University Medical Center, \\ University Dental Clinics, Ljubljana, Slovenia \\ Studij stomatologije na Medicinskom fakultetu u Ljubljani, Slovenija
}

\section{Abstract}

Objectives: To prospectively assess self-perceived chewing function (CF) and oral health-related quality of life $(\mathrm{OHRQ} \mathrm{OL})$ in geriatric patients after receiving three different treatment modalities in the mandible: removable partial denture (CD-RPD), complete denture (CDs), or complete overdenture supported by mini dental implants (CD-MDI). At baseline, all patients had mobile anterior teeth $(1 \mathrm{~mm}$ or $>$ ) and missing posterior teeth in the mandible. Patients were completely edentulous in the maxilla. After treatment, patients were recalled at the 3-month and the 2-year post-treatment period. Materials and Methods: A total of 176 patients participated (CD group, $n=68$; $C D-R P D$ group, $n=58$; CDMDI group, $n=50$ ). Self-reported CF was assessed using the Chewing Function questionnaire (CFO), The OHRQoL was evaluated using the OHIP14 questionnaire, which the patients completed 1 . before treatment, 2. three months after treatment, and 3. at the 2-year post-treatment stage. Results: The OHRQoL and the self-perceived CF significantly improved in all groups after treatment $(p<0.01)$. The highest improvement of a CF was recorded in the CD-MDI group. The OHRQoL was significantly higher in the CD-MDI group in comparison to the CDs group after treatment $(p<0.01)$. At the 2 -year post-treatment stage, self-perceived CF significantly further improved in the CD-MDI group, while it worsened in the CD and the CD-RPD groups $(p<0.01)$. The same pattern was recorded for the OHIP14 summary scores. The highest amount of denture repairs and adjustments was recorded in the CDRPD group, although maintenance was also demanding in the CD-MDI group. Conclusion: Within the limitations of this study, rehabilitation with mandibular MDI retained overdenture can be considered as preferred treatment with the constant improvement of OHRQoL and a chewing function in comparison to mandibular CD or mandibular RPD option in patients with mobile anterior mandibular teeth.
Received: November 10, 2018

Accepted: February 1, 2019

Address for correspondence Professor Asja Čelebić University of Zagreb School of Dental Medicine Department of Removable Prosthodontics

Gundulićeva 5, Zagreb HR-10 000

Croatia

Tel: 014802111

celebic@sfzg.hr

\section{Key words}

Dental Prosthesis; Mandible; Patient Satisfaction; Mastication; Diagnostic Self Evaluation; Geriatric Dentistry

\section{Introduction}

It has been well documented that prosthodontic rehabilitation improves patients' oral health-related quality of life (OHRQoL) (1-3). Treatment modalities for complete or almost complete edentulism in geriatric patients have changed over time, from complete (CDs) and removable partial dentures (RPD) to implant-supported fixed or removable constructions (1-5). Moreover, in the year 2002, a panel of experts in prosthodontics and dental implantology concluded that the restoration of edentulous mandible with convention-
Uvod

Dobro je poznato da protetička rehabilitacija znatno poboljšava kvalitetu pacijentova života ovisnu o oralnome zdravlju (OHRQoL) (1 - 3). Mogućnosti terapije, kad je riječ o potpunoj ili djelomičnoj bezubosti, za osobe starije dobi mijenjale su se tijekom vremena - od potpunih (PP) i djelomičnih proteza (DP) do fiksnih ili mobilnih protetičkih radova na implantatima $(1-5)$. Štoviše, 2002. godine utvrdila je skupina stručnjaka iz područja stomatološke protetike i implantologije da rehabilitacija potpuno bezube donje čelju- 
al complete dentures was no longer the first choice prosthodontic treatment due to overwhelming evidence that a two-implant overdenture should become the first choice of treatment for the edentulous mandible $(6,7)$. However, many geriatric patients are not optimal candidates for placement of dental implants of standard dimensions, either due to their extensive ridge resorption and inadequate buccolingual bone volume, or due to their financial limitations, chronic diseases, or fear to undergo complicated surgical treatments, which include flap reflection, osteotomy and/or different modalities of bone augmentation (8-11).

In the past, dentists needed to compromise and maintain the remaining anterior teeth in the mandible despite their mobility and advanced periodontal disease in order to provide the patients a transient period in which the removable denture would be retained by clasps to allow better retention of removable dentures. Before dental implants had proved their usefulness for removable denture retention and stabilization, keeping teeth with mobility due to the severe bone loss was the only possible option allowing dentists to avoid a complete mandibular denture.

More than a decade ago, slim implants (mini dental implants or MDI) were released to the dental market to support and retain complete dentures. Insertion of MDIs is a quicker and simpler option than the placement of standard size implants (12-15). Most of the time there is also no need for flap reflection (12-25). In many cases, when the insertion torque is adequate (i.e., from 25 up to $45 \mathrm{~N} / \mathrm{cm}^{2}$ ) the MDIs can be immediately loaded $(13,17)$. The MDIs also represent an advantageous option from a financial perspective in comparison to standard size implants, because they are cheaper, and there is no need to purchase abutments as MDIs are onepiece implants. Since the MDIs have been introduced, they have been confirmed as a suitable treatment option in many follow-up studies ranging from six-month to seven years (1226). It has been proven that patients with MDIs and mandibular overdentures achieve even better or at least comparable oral health-related quality of life (OHRQoL) and satisfaction when compared to two standard dental implants $(2,12$ $14,16,20,21)$. Nevertheless, long-term survival rate studies for MDIs are still lacking. The high short-term survival rates of MDIs were only recorded for mandibular overdentures, whereas for maxillary overdentures retained by the MDIs, the short-term survival rates were significantly lower, ranging from 54 to $85 \%(27,28)$. In a study by Maryod et al., delayed loading of MDIs showed better MDI survival rate and less bone loss in comparison to immediate loading in the mandible (15). In a 5-year observational prospective clinical study of immediately loaded new mandibular overdentures on four MDIs, the patient satisfaction increased significantly over five years (13).

However, a self-reported chewing function with MDIs has not been prospectively followed up yet. It has also not been reported yet to which extent MDI-retained mandibular overdentures improve chewing function when compared to patients having CDs in both jaws, or with patients having a maxillary CD and a Kennedy Class I long saddle clasp retained RPD on anterior teeth in the mandible. sti konvencionalnim potpunim protezama više nije prvi izbor protetičke terapije, nego da je to donja pokrovna proteza retinirana na dva implantata $(6,7)$. No mnogim pacijentima starije dobi nije moguće ugraditi implantate standardnih dimenzija zbog značajne resorpcije alveolarne kosti i njezine nedovoljne širine u bukolingvalnom smjeru, zbog pacijentovih financijskih ograničenja, kroničnih bolesti ili straha od kompliciranih kirurških zahvata kao što su odizanje mukoperiostalnog režnja, osteotomija i različiti oblici augmentacije kosti $(8-11)$.

U prošlosti su doktori dentalne medicine često bili prisiljeni na kompromise kako bi sačuvali preostale prednje zube u donjoj čeljusti, čak unatoč njihovoj pokretljivosti i napredovaloj parodontnoj bolesti, jer su tako pacijentima omogućavali prijelazno razdoblje i nošenje djelomične proteze retinirane kvačicama koje su osiguravale bolju retenciju djelomičnih proteza. Prije nego što su se dentalni implantati počeli koristiti za retenciju i stabilizaciju proteza, čuvanje pomičnih zuba sa značajnom resorpcijom kosti bila je jedina opcija koja je omogućavala stomatolozima da izbjegnu izradu potpune proteze u donjoj čeljusti.

Prije više od jednog desetljeća na stomatološkom tržištu pojavili su se uski implantati (minidentalni implantati MDI) za retenciju i stabilizaciju potpunih proteza. Ugradnja MDI-ja brža je i jednostavnija opcija od ugradnje implantata standardnih dimenzija $(12-15)$. U većini slučajeva pri njihovoj ugradnji nema potrebe odizati mukoperiostalni režanj $(12$ - 25). Često, kada je zakretni moment dovoljan (tj. 25 do $45 \mathrm{~N} / \mathrm{cm} 2)$, MDI se može imedijatno opteretiti (13, 17). MDI je također financijski prihvatljiviji u usporedbi s implantatima standardnih dimenzija jer je jeftiniji i nije potrebna kupnja protetičke nadogradnje (abutmenta), s obzirom na to da je MDI jednodijelni implantat. Uz to, utvrđeno je da je MDI prikladna terapijska opcija za retenciju totalnih proteza u mnogim istraživanjima u kojima se pratila njihova klinička funkcija tijekom razdoblja od šest mjeseci do sedam godina $(12$ - 26). Dokazano je da su kvaliteta života ovisna o oralnome zdravlju (OHRQoL) i zadovoljstvo pacijenata $s$ donjim pokrovnim protezama retiniranima na MDI-ju bolji ili približno jednaki kao kod pacijenata s donjim pokrovnim protezama retiniranima na dva implantata standardnih dimenzija $(2,12-14,16,20,21)$. Ipak, još nedostaju dugoročna istraživanja o preživljavanju minidentalnih implantata. Visok postotak preživljavanja MDI-ja zabilježen je samo za donje potpune pokrovne proteze, a za gornje potpune proteze retinirane minidentalnim implantatima postotci preživljavanja bile su značajno niži - u rasponu od 54 do $85 \%$ (27, 28). Maryod i suradnici u svojem su istraživanju utvrdili da je opterećenje MDI-ja u donjoj čeljusti u kasnijoj fazi (nakon oseointegracije) pokazalo veću stopu preživljavanja MDI-ja i manji gubitak marginalne kosti u usporedbi s MDI-jevima koji su bili imedijatno opterećeni (15). U petogodišnjem prospektivnom kliničkom istraživanju utvrđeno je da se pacijentima koji su dobili nove donje potpune proteze retinirane na četiri imedijatno opterećena minidentalna implantata, zadovoljstvo znatno poboljšalo tijekom tih pet godina (13). No žvačna funkcija, kada je procjenjuju sami pacijenti s ugrađenim MDI-jem za retenciju proteza, još uvijek nije prospektiv- 
The main objective of this clinical study was to assess a self-perceived chewing function and OHRQoL in three groups of patients dependent on the type of a new mandibular denture $(\mathrm{CD}, \mathrm{RPD}$, or MDI supported mandibular overdenture (MDI-CD)). Each patient received a new maxillary $\mathrm{CDs}$. The additional aim of the study was to monitor the after-treatment effects of the three prosthodontic treatment options for the mandible over time.

\section{Materials and methods}

All participating patients were informed about the study, and all of them signed the informed consent. The study received the institutional ethical board approval. The patients, who were willing to participate in the study, have been assigned to one of the three study groups and were rehabilitated at the Department of Removable Prosthodontics, School of Dentistry, the University of Zagreb from January 2013 until April 2016.

At baseline, all patients who came seeking treatment were completely edentulous in the maxilla. They had 3-5 mobile anterior teeth in the mandible due to extensive bone loss caused by advanced periodontal disease. The patients were assigned to three different groups. One group comprised of the patients with mobile anterior teeth, which were extracted and the patients were treated with new complete mandibular dentures (CD group). The second group consisted of patients who received mandibular long saddle clasp retained RPDs on the remaining anterior mobile teeth (CD-RPD group). The third group received complete mandibular overdentures supported by four mini dental implants (CD-MDI group) following the extraction of their anterior mandibular teeth.

The selection criteria for the CD-RPD group were: a maxillary CD, mandibular Kennedy Class I status, no teeth distally from the lower canine on one side of the mandibular arch, and no teeth distally from the second incisor on the other side of the arch (i.e., Kennedy Class 1). Furthermore, the remaining teeth had at least grade 1 (less than 1 $\mathrm{mm}$ of perceptible mobility in buccolingual direction) or grade 2 of tooth mobility (i.e., at least $1 \mathrm{~mm}$, but less than $2 \mathrm{~mm})(29,30)$. Due to their mobility, the remaining teeth were not splinted by a fixed partial denture, and therefore it was not possible to use precision or semi-precision attachments. Nineteen patients in the CD-RPD group had five remaining teeth, twenty-five patients had four remaining teeth, and fourteen patients had only three remaining teeth. The CD-RPD patients received long saddle RPDs with lingual plate major connector made of $\mathrm{CoCr}$ alloy to prevent fracture. Cast clasps retained the dentures.

All patients included in this study had suffered a considerable atrophy of the mandibular residual alveolar ridge as no dugoročno praćena. Također nije zabilježeno koliko donje proteze retinirane minidentalnim implantatima poboljšavaju žvačnu funkciju pacijenata u usporedbi s pacijentima koji imaju gornju i donju potpunu protezu ili s pacijentima koji imaju gornju potpunu i donju djelomičnu protezu dugačkih sedala koja je retinirana kvačicama na preostalim prednjim zubima - Kennedyjeva klasa I.

Glavni cilj ovog istraživanja bio je procijeniti žvačnu funkciju i OHRQoL u trima skupinama pacijenata, ovisno o vrsti nove mobilne proteze u donjoj čeljusti [PP, DP ili donja potpuna proteza retinirana na MDI-ju (PP-MDI)]. Svaki od tih pacijenata dobio je i novu potpunu protezu u gornjoj čeljusti. Dodatni cilj istraživanja bio je tijekom godina pratiti učinke tih triju različitih vrsta protetičke rehabilitacije u donjoj čljusti.

\section{Materijali i metode}

Svi pacijenti obaviješteni su o postupcima istraživanja i potpisali su informirani pristanak. Istraživanje je dobilo odobrenje mjerodavnoga etičkog odbora. Pacijenti koji su pristali sudjelovati podijeljeni su u tri grupe te su rehabilitirani u Zavodu za mobilnu protetiku Stomatološkog fakulteta u Zagrebu od siječnja 2013. do travnja 2016. godine.

Pri dolasku svi su pacijenti bili potpuno bezubi u gornjoj čeljusti, a u donjoj su imali od 3 do 5 pomičnih prednjih zuba koji su se klimali zbog opsežnog gubitka kosti kao posljedice parodontne bolesti. Pacijenti su bili podijeljeni u tri skupine. Prva je obuhvatila pacijente čiji su pomični prednji zubi u donjoj čeljusti izvađeni i izrađene su im nove potpune proteze (skupina PP). U drugu skupinu svrstani su oni čiji zubi nisu izvađeni, a rehabilitirani su djelomičnim protezama s dugim produženim sedlima, a retinirane su kvačicama na pomičnim prednjim zubima (skupina PP-DP). U trećoj skupini bili su pacijenti kojima su pomični zubi izvađeni, a napravljene su im pokrovne potpune proteze retinirane na ugrađenim četirima minidentalnim implantatima (skupina PP-MDI).

Kriteriji za izbor u skupinu PP-DP bili su potpuna gornja proteza (PP), Kennedyjeva klasa I u mandibuli, ako je najdistalniji zub s jedne strane očnjak, a s druge drugi inciziv ( $\mathrm{tj}$. Kennedyjeva klasa I). Ti zubi imali su minimalno stupanj 1 (manje od $1 \mathrm{~mm}$ vidljive mobilnosti u bukooralnom smjeru) ili stupanj 2 (tj. minimalno $1 \mathrm{~mm}$, ali manje od $2 \mathrm{~mm}$ ) pomičnosti $(29,30)$. Zbog pomičnosti preostali zubi nisu bili povezani fiksnim radom te zato nije bila moguća upotreba nekih drugih retencijskih elemenata kao što su kopče, nego su napravljene kvačice. Devetnaest pacijenata u skupini PPDP imalo je po pet preostalih zuba, 25 pacijenata po 4, a 14 je imalo samo tri preostala zuba. PP-DP pacijentima izrađene su donje djelomične proteze s produženim sedlima i velikom pločastom spojkom iz $\mathrm{CoCr}$ legure kako bi se spriječili lomovi. Proteze su bile retinirane lijevanim kvačicama.

Svi pacijenti uključeni u istraživanje imali su iznimno izraženu atrofiju donjega alveolarnog grebena distalno s obzirom na to da su već nosili djelomične proteze najmanje pet godina. Početna nakana istraživanja bila je slučajno raspodjeljivanje u skupine. Štoviše, unatoč mogućoj besplatnoj terapiji za sve tri terapijske opcije, neki su pacijenti odbili ugradnju 
they had already been the removable denture wearers for at least five years. The initial study design was that the patients would be randomly assigned to the three groups. Nevertheless, despite the available option to receive free treatment regardless of the three treatment options, some patients refused to accept mini dental implants and were reassigned to the other two groups. Therefore, the study design was modified into the convenience sample study. All costs for MDIs were covered by a research grant (details in the Acknowledgement section). Patients who rejected MDIs for various reasons including fear of surgical procedure, pain, fear of possible medical complications, thoughts they were too old, etc. were allocated into the other two groups. All mandibular dentures were reinforced by a metal framework.

Absolute exclusion criteria for the insertion of the MDI were uncontrolled diabetes mellitus, acute malignant comorbidity including current or recent chemotherapy, intravenous bisphosphonate intake and any history of radiotherapy to the head and neck region. Prior to the MDI placement, panoramic radiographs and/or CBCTs of the mandible were obtained from each participant in the CD-MDI group. All participants receiving MDIs had buccolingual alveolar width of less than $4.5 \mathrm{~mm}$. They received four MDIs intraforaminally in the mandible implanted by a flapless technique (a total of 202 mini-dental implants were inserted, Dentium, South Korea). The implant width and length were chosen based on the residual ridge width and length.

The MDI width was 2.0 or $2.5 \mathrm{~mm}$, while the MDI length varied from $8,10,12$, up to $14 \mathrm{~mm}$. The MDIs were placed following the manufacturer's recommendation using a surgical motor unit (W\&H Implantmed GmbH, Austria) with saline solution for external irrigation for drill cooling and calibrated drills at low speed after punching through the cortical bone. The depth of bone preparation was 1-2 mm less than the length of the roughened surface of implants. Implants were screwed at a torque ranging from 25 up to 45 $\mathrm{N} / \mathrm{cm}^{2}$. The two posterior mini-dental implants were inserted in the tooth location of 34 and 44 in a mature bone, while the position of the two anterior MDIs was dependent on the site of anterior tooth extraction. The implants were inserted near the extraction sites in sites with a mature bone. Only in cases when the extraction socket was very shallow, and the bone anatomy allowed choice of much longer MDIs, the implants were inserted in the extraction socket. The two anterior MDIs were sometimes placed in the sites of mandibular first or second incisors. Antibiotics were prescribed to the patients 2-6 hours prior the MDI insertion and for the following three days. Fifteen days later, when pain from surgery has subsided, impressions for new dentures were obtained. Overdentures were retained by O-ball matrices and were early loaded (6 to 8 weeks after implant insertion). After denture delivery, the patients received detailed instructions on how to maintain oral hygiene with MDIs using a soft toothbrush in the mouth and a hard toothbrush for denture hygiene. The patients who received CDs or CD-RPDs also received instructions about their oral hygiene maintenance. Prosthodontic residents supervised by a specialist of prosthodontics made all dentures. Another specialist of prosthodontics, not minidentalnih implantata te su bili razvrstani u dvije druge skupine. Zato je istraživanje promijenjeno iz randomiziranoga u odgovarajuću oglednu studiju. Svi troškovi za MDI namireni su iz sredstava istraživačkog projekta (detalji u zahvali). Pacijenti koji su odbili ugradnju MDI-ja iz različitih razloga, poput straha od kirurškog postupka, bolova, straha od mogućih komplikacija, dobi itd., bili su uvršteni u druge dvije skupine. Sve donje proteze bile su ojačane metalom.

Apsolutna kontraindikacija za ugradnju MDI-ja bili su nekontrolirani dijabetes melitus, akutne maligne bolesti uključujući trenutačnu ili nedavnu kemoterapiju - intravenska terapija bisfosfonatima i bilo kakva povijest radioterapije u području glave i vrata. Prije ugradnje MDI-ja svim pacijentima u skupini PP-MDI obavljene su ortopantomogramska i/ili CBCT snimka donje čeljusti. Svi pacijenti koji su dobili MDI-je imali su bukolingvalni promjer alveolarnog grebena manji od 4,5 mm. Ugrađena su im četiri MDI-ja intraforaminalno, tehnikom bez odizanja režnja (ukupno su ugrađena 202 MDI-ja Dentium, Južna Koreja). Dimenzija implantata odabrana je na temelju preostale širine i duljine grebena.

Šrina MDI-ja iznosila je 2,0 ili 2,5 mm, a duljina je varirala od 8,10, 12 pa sve do $14 \mathrm{~mm}$. MDI-ji su ugrađeni slijedeći upute proizvođača i uz primjenu fiziodispenzera (W\&H Implantmed GmbH, Austrija) s hlađenjem fiziološkom otopinom i kalibriranim svrdlima na niskim okretajima nakon prolaska kroz kortikalnu kost. Dubina preparacije bila je 1 do $2 \mathrm{~mm}$ manja od duljine aktivne površine implantata. Implantati su ugrađeni primjenom zaokretne sile između 25 i 45 $\mathrm{N} / \mathrm{cm}$. Dva distalna MDI-ja ugrađena su na području zuba 34 i 44, a pozicija prednjih MDI-ja ovisila je o području ekstrakcija zuba. Implantati su ugrađeni blizu područja ekstrakcije, u područja sa zrelom kosti. Samo u slučaju kada je ekstrakcijska rana bila jako plitka, a anatomija kosti dopuštala ugradnju znatno duljih MDI-ja, MDI je ugrađen u ekstrakcijsku alveolu. Dva prednja MDI-ja katkad su bila postavljena u područje prvoga ili drugoga donjeg inciziva. Premedikacija antibioticima određena je svim pacijentima i to od 2 do 6 sati prije operacije te sljedeća tri dana. Petnaest dana nakon ugradnje, kada se bol nakon ugradnje ublažila, uzeti su otisci za nove proteze. Proteze su retinirane s pomoću O-ball gumenih prstena u matricama, a MDI-ji su bili rano opterećeni (6 do 8 tjedana nakon ugradnje). Nakon predaje proteza, pacijentima su dane detaljne upute kako održavati oralnu higijenu s MDI-jem koristeći se mekanim četkicama i tvrdima za čišćcenje proteza.

Pacijenti koji su dobili PP ili DP također su dobili upute o održavanju oralne higijene. Sve proteze izradili su specijalizanti stomatološke protetike pod nadzorom specijalista, tj. mentora. Kvalitetu svih novih proteza (nove potpune proteze u maksili i sva tri tipa proteza u mandibuli) procijenio je specijalist stomatološke protetike koji nije bio uključen u istraživanje i njihovu izradu. Donje pokrovne proteze retinirane miniimplantatima također su bile procijenjene prije ugradnje retencijskih veza. $S$ pomoću Likertove ljestvice od 1 (nezadovoljavajuce) do 5 (odlično), provjeravali su se: rubovi preteza, vertikalna dimenzija te postava zuba. Samo pacijenti čija je proteza bila ocijenjena odličnom ili vrlo dobrom, bili su uključeni u istraživanje za procjenu žvačne funkcije i 
included in the study or in the denture manufacture, assessed the quality of all new dentures (new complete dentures in the maxilla, as well as all three types of removable dentures in the mandible). Mandibular overdentures on MDIs were assessed prior loading. Assessments were made for the denture borders, the vertical dimension of occlusion, and the artificial teeth set-up, by using the Likert scale from 1 (unsatisfactory) to 5 (excellent). Only the patients whose quality of new dentures was assessed as excellent or very good were included in the present study for patients' self-assessment of chewing function and OHRQoL. Throughout the two years after prosthodontic rehabilitation in the mandible, all study participants from all three groups were scheduled for the regular recall visits.

The CD group comprised of 68 patients ( 40 females, 28 males) with the mean age of $69.6 \pm 11.2$ years, of the CD-RPD group 58 patients ( 32 females, 26 males), mean age $66.0 \pm 8.0$, years, and the CD-MDI group comprised 50 patients ( 44 females, 6 males), with the mean age of $66.7 \pm 9.3$ years. All patients from the three groups were previous removable denture wearers.

The Croatian version of the OHIP14 questionnaire (31) and the chewing function questionnaire (CFQ) (32) were completed on three occasions: the first time at baseline immediately before treatment, the second time two to three months after finishing treatment (when all adjustments of new dentures had been completed), and the third time 2 years post-treatment (Fig. 1).
OHRQoL-a. Dvije godine nakon protetičke rehabilitacije u mandibuli, pacijenti iz svih triju grupa pozvani su na redoviti kontrolni pregled.

Skupina PP sastojala se od 68 pacijenata (40 žena, 28 muškaraca) prosječne dobi $69,6 \pm 11,2$ godine, u skupini PPDP bilo je 58 pacijenata (32 žene, 26 muškaraca) prosječne dobi $66,0 \pm 8,0$, a skupina PP-MDI sadržavala je 50 pacijenata (44 žene, 6 muškaraca) prosječne dobi 66,7 $\pm 9,3$ godine. Svi pacijenti, iz svih triju skupina, već su nosili djelomične proteze.

Hrvatske verzije upitnika OHIP 14 (31) i upitnika za procjenu žvačne funkcije (CFQ) (32) ispunjene su tri puta prvi put prije početka terapije, drugi put dva do tri mjeseca nakon završetka terapije (kada su završene sve prilagodbe novih proteza) i treći put dvije godine nakon terapije (slika 1.).

Svaka stavka u OHIP-u 14 traži od pacijenata da odgovore kako često su osjetili ili su se suočili s određenom poteškoćom tijekom posljednjih tjedana (33) i to su označavali kao nikada, rijetko, katkad, često i vrlo često (Likertova ljestvica od 0 do 4). Nula je značila da nema nikakvih problema, a više bodova označavalo je kompromitiranije oralno zdravlje. Pri ispunjavanju upitnika za procjenu žvačne funkcije (CFQ) i upitnika OHIP 14 pacijenti su procjenjivali poteškoće tijekom žvakanja različite vrste hrane u posljednjih tjedan dana (33). Poremećaji žvačne funkcije ocjenjivani su na Likertovoj ljestvici od 0 do 4 ( 0 = nema problema, 4 = najviše poteškoća sa žvakanjem ili nemogućnost žvakanja određene vrste hrane). Za oba upitnika izračunat je zbroj bodova. Raspon zbro-

\section{Oral Health Impact Profile (OHIP-14)}

Chewing Function Questionnaire (CFQ)

\section{Have you had (problems or feelings that)...because of problems with teeth, mouth, dentures?}

\section{Have you had any difficulty chewing foods} such as...(or similar)?
1. Pronouncing words

2. Sense of taste worsened

3. Painful aching (mouth, teeth)

4. Uncomfortable to eat any foods

5. Been self-conscious

6. Felt tense

7. Diet been unsatisfactory

8. Interrupt meals

9. Difficult to relax

10. Feel a bit embarrassed

11. Irritable with people

12. Difficulty doing usual jobs

13. Life in general less satisfying

14. Totally unable to function
1. Apple, pear, raw carrots

2. Bacon, firm meat

3. Biscuits, crackers

4. Fresh bread, doughnut

5. Nuts, pecan, almonds, peanuts, macadamia

6. Lettuce, raw cabbage

7. Biting different foods, incision

8. Chewing gum

9. Have you felt insecure when chewing

10. Have you noticed food catching on your teeth or tooth replacement 
For each of the OHIP14 items, the patients were asked how frequently they had experienced the impact during the previous week (33). The five categories of choice per item were never, rarely, occasionally, often, and very often; (Likert scale from 0 to 4). Zero indicated an absence of problems, while higher scores indicated more impaired oral health. When filling-in the CFQ or the OHIP14 questionnaire, the patients were asked to assess their difficulties while chewing different foods during the previous week (33). The CFQ answers were graded on the Likert scale from 0 to $4(0=a b-$ sence of problems, up to $4=$ the highest problem or inability to chew specific food). For both questionnaires, summary scores were used for statistical analysis. Summary scores for the OHIP14 questionnaire range from zero to 56 , and the summary scores for the CFQ range from zero to 40 .

Statistical analysis (SPSS 20 for Windows, IBM) included one sample Kolmogorov-Smirnov test for testing normality of the data distribution, descriptive statistics, paired t-test (pretreatment vs. post-treatment data), and one-way ANOVA (post hoc Scheffe's test). The linear mixed model was also used (summary scores were dependent variables; treatment option, gender, and level of education were fixed factors; age was a covariate). P values $<.05$ were considered statistically significant.

\section{Results}

All summary scores were normally distributed $(\mathrm{P}>0.05)$. There were no statistically significant differences in age between the three study groups $(\mathrm{F}=2.42 ; \mathrm{P}=0.092)$.

In the CD-MDI group, two mini-dental implant heads broke during insertion in two different patients. Broken implants were left as „sleeping implants“, however, the respective patients received a new MDI, each. Three additional implants were lost during the first 6-8 weeks (in three different patients) who received mandibular overdenture retained with only three MDIs (instead of four). Two additional MDIs were lost during the first year, and no MDI was lost during the second year, resulting in the $97 \%$ implant treatment survival rate. There were also no clinical signs of moderate or advanced peri-implantitis according to classification for peri-implantitis proposed by Froum and Rosen (34). No significant problems with dentures were registered in the CDMDI group, and no fracture repairs were necessary. Four patients needed additional adjustments due to sore spots, two matrices were loosened and were remounted, and a total of 34 O-rings (17\%) were changed in different patients.

In the CD-RPD group, fourteen teeth were lost in the mandible (in nine patients) and were replaced by acrylic teeth in the respective dentures. If the abutment tooth was lost, the new wire clasp was made on the adjacent tooth. Five clasps were broken in seven patients and they were repaired. Twenty-three patients reported clasp loosening several times and came to a dental office for clasp activation. Thirteen patients reported sore spots after the period of adjustment (the first three months). In the $\mathrm{CD}$ group, twenty-four patients required additional adjustments due to sore spots, while four patients required a mandibular denture relining. Differenc- ja bodova upitnika OHIP 14 može biti od 0 do 56, a CFQ-a od 0 do 40.

Za statističku obradu (SPSS 20 for Windows, IBM) korišten je Kolmogorov-Smirnovljev test za ispitivanje normalnosti distribucije, testovi za deskriptivnu analizu, t-test za zavisne uzorke (prije terapije; poslije terapije) i jednosmjerna ANOVA (post hoc Schefferov test). Linearni miješani model (general linear model) također je korišten (zbroj bodova u upitniku bile su zavisne varijable, terapijske mogućnosti (3 skupine), spol i razina edukacije bili su fiksni čimbenici, a dob je bila kovarijanta. P vrijednost od $<, 05$ smatrala se statistički značajnom.

\section{Rezultati}

Zbrojevi bodova svih upitnika bili su normalno raspodijeljeni $(P>0,05)$. Nije bilo statistički značajnih razlika kad je riječ o dobi pacijenata između triju ispitivanih skupina $(\mathrm{F}=$ $2,42 ; \mathrm{P}=0,092)$. U skupini PP-MDI slomile su se dvije glave miniimplantata tijekom ugradnje dvama pacijentima. Frakturirani implantati ostavljeni su u koštanom tkivu rezidualnog alveolarnog grebena mandibule kao spavajuci implantati, no svaki je pacijent dobio dodatno jedan novi MDI umjesto puknutoga. Još tri miniimplantata izgubljena su u prvih šest do osam tjedana nakon ugradnje (kod tri pacijenta). Ti pacijenti dobili su donju pokrovnu protezu retiniranu samo na preostalim miniimplantatima (na trima preostalima, umjesto na četirima). Tijekom prve godine u funkciji izgubljena su još dva MDI-ja, a tijekom druge nije izgubljen ni jedan, što je rezultiralo ukupnim postotkom preživljavanja miniimplantata od $97 \%$ tijekom dvije godine. Također, u ovoj skupini pacijenata, čije su donje pokrovne proteze bile retinirane na miniimplantatima (skupina PP-MDI) nije bilo kliničkih znakova umjerenog ili napredovalog periimplantitisa prema klasifikaciji koju su predložili Froum i Rosen (34). Nisu bili zabilježeni nikakvi veći problemi s protezama te nije bilo potrebe za reparaturama zbog puknuća. Četiri pacijenta trebala su dodatna prilagođavanja proteze nakon prva tri mjeseca zbog bolnih mjesta na ležištu - dvije matrice u protezama rasklimale su se te su ponovno montirane (učvršćene). Tijekom dvije godine različitim pacijentima promijenjena su i $34 \mathrm{gu}-$ mena O-prstena (17\%).

U skupini PP-DP (u maksili potpuna proteza, djelomična u mandibuli) tijekom dvije godine četrnaest zuba izgubljeno je u mandibuli (kod devet pacijenata). Izvađeni zubi nadoknađeni su u odgovarajućim protezama u koje su dodani 


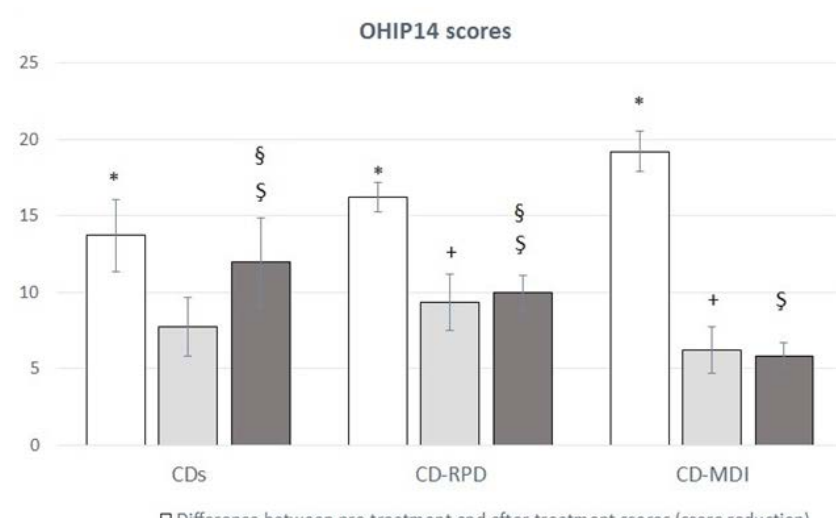

口3-month after treatment scores

a 2 years after treatment scores

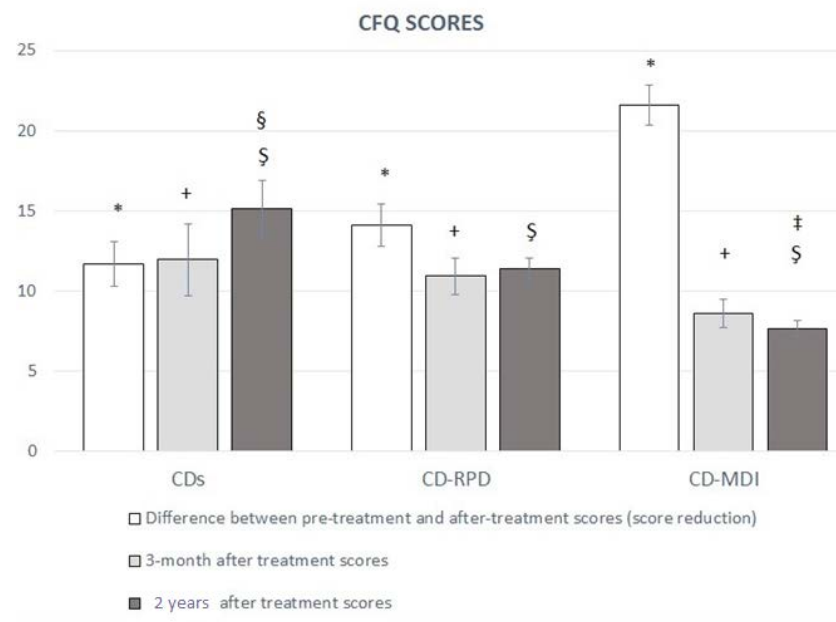

es between the baseline-, the after-treatment-, and the 2-year post-treatment summary scores are presented separately for the CFQ, and the OHIP14 scores (Figure 2 and Figure 3, respectively).

The treatment significantly reduced both, the OHIP14 and the CFQ scores in comparison to the baseline scores in all treatment groups $(\mathrm{p}<0.001)$. However, the amount of score reduction was significantly different among treatment groups $(\mathrm{F}=4.95, \mathrm{p}=0.008$ for the OHIP14; $\mathrm{F}=30.39, \mathrm{p}<0.001$ for the CFQ). The CFQ score reduction was significantly higher in the CD-MDI group than in both, the CD group (mean difference $=-9.89 ; \mathrm{p}<0.001$, Scheffe post hoc $)$ and the CDRPD group (mean difference $=-7.53 ; \mathrm{p}<0.001$, Scheffe post hoc). The OHIP14 score reduction was significantly higher in the CD-MDI group than in the CD group (mean difference $=-5.49 ; \mathrm{p}=0.008$, Scheffe post hoc).
Figure 2 OHIP14 summary scores (histograms) with 95\% confidence intervals in complete denture wearers (CD), mandibular removable partial long saddle denture (Kennedy Class I) (CD-RPD), and in mini dental implant retained mandibular overdentures (CD-MDI). * =significant difference between patient groups for the amount of score reduction $(p<0.05)$, $+=$ significant differences between patient groups for the 3-month after treatment scores; S=significant differences between patient groups for the 1-year after treatment scores, $\S=$ significant score increase in relation to the 3-month after treatment scores.

Slika 2. Zbroj bodova upitnika OHIP 14; histogrami s 95-postotnim intervalima pouzdanosti kod nositelja potpunih proteza (CD), djelomičnih mobilnih proteza dugih sedala (Kennedyjeva klasa I) (CD-RPD) te kod pacijenata s donjim pokrovnim potpunim protezama retiniranima na minizubnim implantatima (CD-MDI). * = značajna razlika između skupina pacijenata za iznos smanjenja broja bodova $(p<0,05),+$ = značajne razlike između skupina pacijenata tri mjeseca nakon predaje proteza; S = značajne razlike između skupina pacijenata dvije godine nakon predaje proteza, $\S$ = značajno povećanje broja bodova u odnosu prema rezultatima tri mjeseca nakon predaje proteza
Figure 3 Summary Scores of the Chewing Function Questionnaire (CFQ) (histograms) with 95\% confidence intervals in complete denture wearers (CD), removable partial, long saddle mandibular denture wearers (Kennedy Class I, CD$\mathrm{RPD}$ ), and in mini dental implant retained mandibular overdentures (CD-MDI). * =significant difference between patient groups for the amount of score reduction $(p<0.05)$, $+=$ significant differences between patient groups for the 3-month after treatment scores, Ş=significant differences between patient groups for the 1-year after treatment scores, $\S=$ significant score increase in relation to the 3-month after treatment scores, $\ddagger=$ significant score decrease in relation to the 3-month after-treatment scores.

Slika 3. Zbroj bodova upitnika za procijenu žvakanja (CFO); histogrami s 95-postotnim intervalima pouzdanosti kod pacijenata s potpunim protezama (CD), djelomičnim mobilnim protezama dugačkih sedala (Kennedyjeva klasa I, (D-RPD) i potpunim pokrovnim protezama retiniranima na miniimplantatima (CD-MDI); * = značajna razlika između triju skupina pacijenata ovisno o smanjenju broja bodova nakon terapije $(\mathrm{p}<0,05) ;+=$ značajna razlika između triju skupina pacijenata nakon terapije i prilagodbe (tri mjeseca nakon predaje proteza); Ş = značajna razlika između triju skupina pacijenata nakon dvije godine nošenja proteza; $\S$ = značajno povećanje zbroja bodova u odnosu prema razdoblju nakon terapije i tri mjeseca prilagodbe; $¥=$ značajno smanjenje zbroja bodova u odnosu prema razdoblju nakon terapije i tri mjeseca prilagodbe

akrilatni umjetni zubi, a napravljene su i nove žičane kvačice na susjednim zubima u slučaju kada je bio izvađen zub nosač (uporišni zub). Puknulo je i sedam kvačica petorim pacijentima, što je također popravljeno. Dvadeset i tri pacijenta više su puta dolazili u stomatološku ordinaciju zbog gubitka retencije kvačica te su one aktivirane. Trinaest pacijenata prijavilo je bolna mjesta nakon završenog razdoblja prilagodbe (prva tri mjeseca) te su im proteze dodatno prilagođene (izbrušen je višak materijala). U skupini PP (obje potpune proteze) dvadeset i četiri pacijenta trebala su dodatne prilagodbe proteza zbog bolnih mjesta (nakon završene prilagodbe, dakle nakon više od tri mjeseca), a četiri pacijenta tražila su podlaganje mandibularnih proteza.

Značajnost razlika između početnih vrijednosti (dobivenih prije početka protetičke terapije), vrijednosti dobivene nakon završene terapije i prilagodbe na novi protetički rad te 
The three-month after-treatment (when patients were adjusted to their dentures) summary scores were significantly different among groups $(\mathrm{F}=4.84, \mathrm{p}=0.009$ for the OHIP14 questionnaire; $\mathrm{F}=7.93, \mathrm{p}=0.001$ for the $\mathrm{CFQ}$ ). The $\mathrm{CD}$ MDI group had significantly lower OHIP14 scores than the CD-RPD group (mean difference $=-3.18 ; \mathrm{p}=0.009$, Scheffe post hoc). Moreover, the CD-MDI group had significantly lower CFQ scores than both, the CD group (mean difference $=-3.34 ; p=0.001$, Scheffe post hoc) and the CD-RPD group (mean difference $=-2.31 ; \mathrm{p}=0.030$, Scheffe post hoc).

Multivariate analysis (linear model) analyzed the effect of variables: treatment option, gender, level of education and age on the dependent variable (Summary score) and revealed that only treatment option yielded to significant effects $(\mathrm{p}=0.030)$ regarding the OHIP14 summary scores, while age $(\mathrm{p}=0.203)$, gender $(\mathrm{p}=0.160)$, and level of education $(\mathrm{p}=0.340)$ did not. Similar results were registered for the CFQ after treatment summary scores. The only significant effect was elicited by the treatment option $(p=0.002)$, while gender $(p=0.390)$, age $(\mathrm{p}=0.287)$, and the level of education $(\mathrm{p}=0.172)$ yielded no significant effects.

Two years after the prosthodontic rehabilitation, the CFQ ( $\mathrm{t}=12.18, \mathrm{p}<0.001)$, as well as OHIP14 scores ( $\mathrm{t}=7.19$, $\mathrm{p}<0.001$ ) significantly increased (more difficulties) in the CD group $(\mathrm{p}<0.001)$ compared to the three-month after-treatment results. In the CD-RPD group, the OHIP14 summary scores significantly increased $(t=2.15, p=0.036)$. In the CD-MDI group, the OHIP14 scores remained stable (even slightly decreased), whereas the CFQ scores were significantly smaller compared with the post-treatment scores $(t=5.609$, $\mathrm{p}<0.001)$.

\section{Discussion}

The CD-MDI group benefited most from the treatment, compared to the $\mathrm{CD}$ and the CD-RPD groups. The patients in the CD-MDI group improved both, self-perceived vrijednosti dobivene nakon dvije godine kliničkog praćenja, prikazane su odvojeno za zbroj bodova CFQ-a i za zbroj bodova OHIP-14 (slika 2. i slika 3.).

Provedena terapija značajno je smanjila zbroj bodova obaju upitnika - OHIP-a 14 i CFQ-a, u odnosu prema početnim vrijednostima prije terapije $(\mathrm{p}<0,01)$ u svim skupinama pacijenata. No smanjenje bodova u upitniku značajno se razlikovalo između pojedinih skupina $(\mathrm{F}=4,95, \mathrm{p}=0,008 \mathrm{za}$ OHIP 14; $\mathrm{F}=30,39, \mathrm{p}<0,001$ za CFQ). Tako se zbroj bodova za CFQ značajno više smanjio u skupini PP-MDI, negoli u drugima dvjema (u odnosu prema skupini PP aritmetička sredina razlike iznosila je $-9,89 ; p<0,01-$ Shefferov post hoc test, a u odnosu prema skupini PP-DP srednja razlika bila je -7,35; $\mathrm{p}<0,001-$ Schefferov post hoc test). Smanjenje bodova OHIP 14 upitnika bilo je značajno veće u skupini PP-MDI negoli u skupini PP (srednja razlika $=-5,49$; $\mathrm{p}$ $=0,008-$ Schefferov post hoc test).

Nakon predaje novih radova i tromjesečne prilagodbe na novi protetički rad, zbrojevi bodova upitnika bili su značajno različiti između triju skupina $(F=4,84, p=0,009$ za upitnik OHIP 14; $F=7,93, p=0,001$ za CFQ). Skupina PP-MDI imala je značajno niži zbroj bodova OHIP 14 upitnika negoli CD-DP (srednja razlika $=-3,18 ; \mathrm{p}=0,009$ - Schefferov post hoc test). Štoviše, skupina PP-MDI imala je i značajno niže vrijednosti zbroja bodova CFQ-a negoli druge dvije skupine pacijenata. Za skupinu PP srednja razlika iznosila je -3,34; $p=0,001-$ Schefferov post hoc test, a za skupinu PP-DP srednja razlika bila je -2,31; $\mathrm{p}=0,030$ Schefferov post hoc test.

Multivarijantnom analizom (linearni model) ispitan je utjecaj raznih varijabli, poput vrste terapije (PP-DP, PP, PPMDI), spola, stupnja obrazovanja i dobi na zavisnu varijablu (zbroj bodova upitnika) te je otkriveno da je samo vrsta protetičke terapije pokazala značajne učinke $(\mathrm{p}=0,030)$ vezano za zbroj bodova OHIP 14 , a dob $(\mathrm{p}=0,203)$, spol $(\mathrm{p}=$ $0,160)$ i stupanj obrazovanja $(\mathrm{p}=0,340)$ nisu pokazali značajan utjecaj. Slični rezultati zabilježeni su i za zbroj bodova upitnika o funkciji žvakanja (CFQ) nakon terapije. Jedini značajan učinak na promjenu bodova izazvan je opcijom protetickki tretman (vrsta terapije) $(\mathrm{p}=0,002)$, a spol $(\mathrm{p}=0,390)$, $\operatorname{dob}(\mathrm{p}=0,287)$ i stupanj obrazovanja $(\mathrm{p}=0,172)$ nisu pokazali značajne učinke.

Dvije godine nakon protetičke rehabilitacije zbrojevi bodova CFQ-a $(\mathrm{t}=12,18, \mathrm{p}<0,001)$ i OHIP-a $14(\mathrm{t}=7,19$, $\mathrm{p}<0,001)$ značajno su porasli (upućuje na više poteškoća) $\mathrm{u}$ skupini PP ( $\mathrm{p}<0,001)$ u odnosu prema razdoblju neposredno nakon insercije novih proteza. U skupini PP-DP zbroj bodova u upitniku OHIP 14 značajno je porastao $(t=2,15, \mathrm{p}$ $=0,036)$. U skupini PP-MDI rezultati OHIP-a 14 ostali su stabilni (čak su se malo smanjili), a bodovi CFQ-a bili su značajno manji u usporedbi s rezultatima nakon predaje proteza $(t=5,609, p<0,001)$.

\section{Rasprava}

Skupina PP-MDI imala je najviše koristi od terapije, u usporedbi sa skupinama PP i PP-DP. U skupini PP-MDI popravili su se žvačna funkcija (prema procjeni samih pacije- 
chewing function and OHRQoL better than the other two groups. The OHRQoL and the chewing function worsened throughout the first two years in the CD and the CD-RPD groups, while in the CD-MDI group the chewing function showed further improvement.

In general, almost all prosthodontic rehabilitation options show high initial treatment effects $(1,35-37)$, which is in accordance with the results of this study. For the overdentures retained by the standard size implants, the excellent initial and long-term treatment effects have already been proven (14,35). The CD-MDI treatment in the mandible has become a viable treatment option for patients with atrophic alveolar ridges and/or for those with financial limitations $(2,13$ 23,24-26). One study showed that patients with mandibular overdenture retained with four MDIs had a better OHRQoL in comparison to those with bar and locator overdentures retained by two standard size implants throughout a period of three years (2). Chewing function in patients with the MDI retained overdenture has not been assessed or compared with patients receiving other treatments yet. Therefore, we evaluated patients with three different prosthodontic rehabilitation options in the mandible considering both, OHRQoL and a self-perceived chewing function. All patients had a CD in the maxilla, and all patients were of similar age.

The long saddle mucosa born clasp-retained RPD group of patients represented a transient alternative to complete edentulism. Anterior mandibular teeth usually remain as last surviving teeth in patients' mouth (38-40). Prior dental implants utilization, dentists often preserved mobile anterior mandibular teeth in order to use them for denture retention by clasps to provide a slow transition to the complete mandibular denture. The retention of mandibular CDs depends only on factors such as interfacial surface tension, gravity, a viscosity of the saliva, anatomical and mechanical factors of a denture bearing area, and muscular coordination (40-43). Apart from keeping the last remaining teeth, a contemporary dentist has the alternative to insert dental implants to solve problems inherent to complete denture wearing. The MDI can be used in patients who would otherwise need bone augmentation, and this allows inclusion of a higher number of potential implant patients and less expensive and invasive treatment modalities.

The patients in this study were first offered to receive four MDIs, without any charge, as the research grant covered the costs of implants. Most of the patients who refused the MDI therapy explained that it was due to their fear of pain or fear of possible complications due to their old age, while some of them declined MDIs due to sufficient satisfaction with their old dentures. All patients who refused MDIs were assigned into the $\mathrm{CD}$ or RPD groups. The MDI overdentures in this study were early loaded, as this was reported to be a better option than the immediate loading protocol (15).

The impact of oral interventions on individually selfperceived oral health outcomes has been recognized as an important health component $(1,2,4,13,23,24,31-33,36$ $38,40-50,53,58-60)$. We, therefore, decided to use the selfperceived measures, namely the OHIP14 and the CFQ to assess treatment outcomes. A recent study showed that self- nata) i OHRQoL i to više negoli u ostalim dvjema. Žvačna funkcija i OHRQoL pogoršavali su se tijekom prve dvije godine u drugim dvjema skupinama, tj. u PP-u i PP-DP-u, a u skupini PP-MDI pokazivala je daljnje poboljšanje. Općenito, gotovo svaki protetičko-rehabilitacijski postupak pokazuje inicijalno poboljšanje $(1,35$ - 37), što je u skladu i s rezultatima u ovom istraživanju. Prema podatcima iz literature, pokrovne proteze retinirane standardnim implantatima pokazuju izvrsne inicijalne i dugotrajne rezultate $(1-4,35)$. Terapija PP-MDI u donjoj čeljusti postala je metoda izbora za pacijente $s$ atrofičnim alveolarnim grebenom i/ili za one $s$ financijskim ograničenjima $(2,13-23,24-26)$. Istraživanje je pokazalo da pacijenti s pokrovnom protezom retiniranom $s$ četirima MDI-ja imaju bolji OHRQoL u usporedbi s pacijentima s pokrovnim protezama retiniranima prečkom ili lokatorima na dvama implantatima standardnih dimenzija tijekom trogodišnjeg razdoblja (2). Žvačna funkcija pacijenata s pokrovnim protezama retiniranima MDI-jem još se nije procjenjivala ili uspoređivala s drugim oblicima terapije. U skladu $s$ tim, u ovom istraživanju procjenjivali smo pacijente $s$ trima različitim vrstama protetičke terapije u donjoj čeljusti, uzimajući u obzir OHRQoL i žvačnu funkciju. Svi pacijenti imali su potpunu protezu u gornjoj čeljusti i svi su bili približno iste dobi. Skupina pacijenata s djelomičnim protezama dugih produženih sedala, koje su bile retinirane kvačicama, bila je alternativa potpunoj bezubosti. Prednji donji zubi obično ostaju kao posljednji u čeljusti $(38-40)$. Prije primjene implantata, doktori dentalne medicine nastojali su sačuvati čak i djelomično pomične prednje donje zube s namjerom da ih iskoriste kao retencijske - za nosače kvačica - $\mathrm{i}$ tako odgode prelazak na potpune proteze. Retencija potpune donje proteze ovisi o čimbenicima kao što su gravitacija, viskoznost sline, anatomski i mehanički čimbenici, odnos rubova proteze prema mekim tkivima i o mišićnoj koordinaciji pacijenata $(40-43)$. Uz očuvanje preostalih zuba, današnji doktori dentalne medicine imaju mogućnost ugradnje dentalnih implantata kako bi riješili probleme koji otežavaju nošenje proteze. MDI-jem se mogu koristiti i pacijenti koji bi za ugradnju implantata standardnih dimenzija morali proći postupak augmentacije, te je zato moguće uključiti i veći broj potencijalno implantoprotetičkih pacijenata u terapiju, uz manje troškove i manje invazivne terapijske postupke.

Pacijentima je u ovom istraživanju najprije bila ponuđena ugradnja četiriju MDI-ja, bez troškova, jer bi se oni pokrili financiranjem projekta. Većina pacijenata koji su odbili tu terapiju objasnili su svoj postupak strahom od bolova ili mogućih komplikacija zbog dobi, a dio njih bio je zadovoljan dosadašnjim starim protezama. Svi pacijenti koji su odbili MDI bili su raspoređeni u skupine PP ili PP-DP. Pokrovne proteze retinirane MDI-jem bile su rano opterećene, u skladu s podatcima iz literature koji pokazuju da je to bolja opcija negoli imedijatno opterećenje (15). Utjecaj rehabilitacijskih oralnih zahvata na individualno doživljavanje rezultata terapije prepoznat je kao važna komponenta zdravlja $(1,2,4,13,23$, $24,31-33,36-38,40-50,53,58-60)$. U skladu s tim u istraživanje smo uključili upitnike OHIP 14 i CFQ, kako bismo procijenili uspjeh terapije na temelju mišljenja samog pacijenta. Suvremena istraživanja pokazuju da samoprocjena 
perceived chewing ability and objective mixing ability (chewing) have been significantly inter-related (42). Although recent studies showed that the OHRQoL comprises of four dimensions $(33,34,36-48)$, only the summary scores of the OHIP14 questionnaire have been assessed in this study, as it is the most frequently used questionnaire in prospective oral health-related quality of life assessment (49)). Although the OHIP14 shows lower sensitivity in the edentulous patients than the OHIP-EDENT (50), it was preferred in this study, because the CD-RPD group had some anterior teeth left in the mandible and were not suitable for the OHIP-EDENT questionnaire.

As expected, all treatment options elicited significant treatment effects, which were confirmed by a significant after-treatment score reduction. However, excellent benefits of the CD-MDI treatment considering both, chewing function, and OHRQoL, in comparison to the CD and the CD-RPD group, have been proven in the study. Despite the fact that the CD-RPD group had clasps to improve denture retention and stability, the CD-MDI group revealed significantly better after-treatment chewing scores, probably due to better retention and stability of dentures provided by MDI matrices with "O" rings than by clasps on the remaining teeth in the CD-RPD group, regardless of how many teeth had been present (three, four or five) or what was their position and/ or condition. Significantly better OHIP14 after treatment scores in the CD-MDI group than in the CD-RPD group could additionally be attributed to aesthetic concerns (clasp visibility in the CD-RPD group), and not solely to the selfperceived chewing function in the CD-MDI group.

However, two years after denture insertion, both OHRQoL and the chewing function worsened (i.e. confirmed by increased questionnaires scores) in the $\mathrm{CD}$ patients and in the CD-RPD group, which we attributed to problems inherent to removable denture wearing, such as residual ridge resorption, mucosal inflammation and/or clasp loosening (50-59). Scores of the CFQ, as well as the OHIP14 were not dependent on the position and number of the remaining teeth in the CD-RPD group. On the contrary, the OHIP14 scores slightly decreased further and the CFQ scores significantly reduced in the CD-MDI patients (revealing further improvement), which we attributed to patient's better adaptation to their dentures and subsequent increased confidence and stability while chewing at the 2-year observation stage. The results related to OHRQoL are in agreement with some other authors reporting that patient satisfaction with miniimplant retained mandibular overdentures increased significantly with time $(2,13,22)$. ELsyad et al. reported that patient satisfaction with MDI treatment increased considerably with time over five years, especially for eating (hard/soft) food, the comfort of denture wearing, stability/retention of mandibular dentures, ease of oral hygiene and ease of handling the dentures (13). However, the results of a self-perceived chewing function are reported for the first time in this study for MDI retained overdenture patients.

After initial adjustments, the CD-MDI group had no significant repairs or additional adjustments through the first two years as well as no fractures due to metal skeleton rein- žvačne sposobnosti i objektivna procjena sposobnosti žvakanja pokazuju značajnu povezanost (42). Premda novije studije pokazuju da se OHRQoL sastoji od četiriju dimenzija (33, 34, 36 - 48), samo ukupan zbroj bodova OHIP-a 14 uključen je u ovo istraživanje, a taj se upitnik najčešće upotrebljava u dugotrajnim istraživanjima za procjenu kvalitete života ovisne o oralnom zdravlju (49).

Premda OHIP 14 pokazuje manju osjetljivost bezubih pacijenata od upitnika OHIP-EDENT (50), pogodniji je za ovo istraživanje zbog skupine PP-DP koja još ima prednje zube preostale u donjoj čeljusti. Tako ta skupina nije pogodna za OHIP-EDENT.

Kako se i očekivalo, sve vrste terapija pokazale su značajne učinke koji su potvrđeni znatnim smanjenjem ukupnog zbroja bodova nakon terapije. No u ovom istraživanju dokazana je veća dobrobit PP-MDI terapije, uključujući i žvačnu funkciju i kvalitetu života, u usporedbi sa skupinama PP i PP-DP. Unatoč činjenici da je skupina PP-DP imala kvačice koje poboljšavaju retenciju i stabilizaciju proteza, skupina PP-MDI pokazala je značajno bolju mogućnosti žvakanja nakon terapije, vjerojatno zbog bolje retencije i stabilizacije donjih proteza koje su bile osigurane retencijskim matricama, tzv. $O$ prstenima. Ta je retencija bolja negoli retencija i stabilizacija kvačicama na preostalim zubima u skupini PP-DP, bez obzira na to koliko je bilo retencijskih zuba (tri, četiri ili pet) ili kako su bili raspoređeni u čeljusti. Stanje preostalih zuba nije utjecalo na rezultat. Značajno veći zbroj bodova u upitniku OHIP 14 nakon terapije zabilježen je u skupini PP-MDI, negoli u skupini PP-DP, što se dodatno može pripisati i estetskim razlozima (vidljivost kvačica u skupini PP-DP), a ne samo samoprocjeni žvačne funkcije u skupini PP-MDI.

No dvije godine nakon predaje proteza, OHRQoL i žvačna funkcija pogoršali su se (potvrđeno povećanjem ukupnog zbroja bodova upitnika) kod PP pacijenata i u skupini PPDP. To se može pripisati problemima povezanima uz nošenje proteza (kao što su resorpcija preostalog alveolnog grebena), upali sluznice i/ili popuštanju retencije kvačica $(50-59)$. Bodovi u upitnicima CFQ i OHIP 14 nisu ovisili o položaju i broju preostalih retencijskih zuba u skupini PP-DP. Nasuprot ovim skupinama, ukupan zbroj bodova u OHIP-u 14 smanjio se tijekom vremena, a zbroj bodova u CFQ-u značajno se smanjio u skupini PP-MDI (pokazujući daljnje poboljšanje), što pripisujemo boljoj prilagodbi pacijenata na proteze i posljedičnom povećanju samopouzdanja te sigurnosti tijekom žvakanja u dvogodišnjem razdoblju.

Rezultati u ovom istraživanju dobiveni za OHRQoL slični su rezultatima drugih autora koji su ustanovili da zadovoljstvo pacijenata pokrovnim protezama retiniranima miniimplantatima raste tijekom godina $(2,13,22)$.

Elsyad i suradnici istaknuli su da zadovoljstvo pacijenata MDI-jem raste značajno tijekom razdoblja od pet godina. To se posebno odnosi na žvakanje (tvrde/meke) hrane, ugodnost pri nošenju proteza, stabilnost/retenciju donjih proteza, jednostavno održavanje oralne higijene i manipulaciju protezama (13). No rezultati povezani sa žvačnom funkcijom kod pacijenata s pokrovnim protezama retiniranima minidentalnim implantatima prvi se put spominju u ovom istraživanju. Nakon početne prilagodbe, skupina PP-MDI nije imala ve- 
forcement. The number of patients who asked for further adjustments was the highest in the RPD group. The respective group had the highest amount of repairs due to the extractions of some of the remaining teeth over time. Although two matrices were loosened and repaired and $17 \%$ of O-rings had to be changed after two years, which may be considered demanding maintenance, the MDI treatment option showed to be superior to other options, as it showed the highest and persistent, even improving results over time regarding the chewing function and OHRQoL. When compromised teeth due to non-treated active periodontal disease are left in the mouth for better denture retention and support, it may have a harmful effect on the systemic health of geriatric patients $(56,61)$. Therefore, the MDI retained mandibular overdenture can be considered a safer option than keeping teeth with active periodontal disease, specifically in geriatric patients with systemic diseases, although we need to be aware that MDI can also be affected by peri-implantitis, which can harbor infection not beneficial to this patient population.

The limitations of the study include relatively small sample size, differences in number, position, and degree of mobility of remaining teeth in the CD-RPD group, some differences regarding bone volume, i.e., residual ridge atrophy in the maxilla and in the mandible and relatively short observation period. An assessment of the patient's personality was also not performed.

\section{Conclusions}

Patients receiving mandibular overdentures retained by mini dental implants showed the highest improvement of OHRQoL and chewing function, consistent and even improved over the period of 2 years in comparison to patients who received a complete mandibular denture or a long saddle clasp retained Kennedy class I partial removable denture on slightly mobile anterior teeth.

\section{Acknowledgments}

Research reported in this publication was supported by the Croatian Science Foundation under research project entitled Defining possibilities of using Mini dental implants (MDI) and assessment of their outcomes in vitro and clinical randomized prospective studies (code 1218).

\section{Conflict of interest}

The authors report no conflict of interest. ćih popravaka ili dodatnih prilagođavanja proteza tijekom prve dvije godine nošenja. Također nije bilo ni puknuća proteza zbog njihove lijevane metalne osnove. Broj pacijenata koji su trebali dodatno prilagođavanje proteza bio je najveći u skupini PP-DP. Ta je skupina imala najviše popravaka i prilagodbi proteza zbog vađenja nekih retencijskih zuba tijekom godina. Iako su u skupini PP-MDI dvije matrice izgubile retencijsku silu i morale su biti ponovo pričvršćene, a $17 \%$ $O$ gumenih prstenova moralo je biti zamijenjeno nakon dvije godine (što se smatra nešto zahtjevnijim održavanjem), terapija se u toj skupini pokazala superiornijom u usporedbi s ostalim dvjema opcijama. Imala je i najbolje najperzistentnije dugotrajne rezultate, povećavajući zadovoljstvo pacijenata tijekom godina, posebno žvačnu funkciju i OHRQoL.

Kada se parodontno kompromitirani zubi ostavljaju u ustima kako bi se postigla bolja retencija i stabilizacija proteza, to može pogubno djelovati na sistemsko zdravlje gerijatrijskih pacijenata $(56,61)$. Sukladno tomu, pokrovne proteze retinirane MDI-jem mogu se smatrati sigurnijim rješenjem negoli očuvanje zuba s aktivnim parodontnim upalnim procesom, posebno kod gerijatrijskih pacijenata sa sistemskim bolestima. No moramo biti svjesni da MDI također može biti zahvaćen periimplantitisom, a to je zapravo način za ulazak infekcije koje nikako nisu poželjne pacijentima ove dobne skupine.

Ograničenja u ovom istraživanju uključuju razmjerno mali broj ispitanika, razlike u broju, položaju i stupnju pokretljivosti preostalih zuba u skupini PP-DP pacijenata. Također postoje razlike u volumenu kosti, resorpciji alveolnog grebena u gornjoj i donjoj čeljusti te relativno kratko vrijeme za provedbu istraživanja. Procjena osobnosti pacijenta također nije učinjena.

\section{Zaključak}

Pacijenti koji su dobili donje pokrovne proteze retinirane minidentalnim implantatima pokazali su najveće poboljšanje OHRQoL-a i žvačne funkcije. OHRQoL i žvačna funkcija u toj su skupini pacijenata ostali konzistentni ili su se dodatno poboljšali tijekom dvije godine u odnosu prema pacijentima koji su dobili donje potpune proteze ili djelomične proteze s dugačkim produženim sedlima Kennedy klase I, a koje su bile retinirane kvačicama na preostalim blago pomičnim prednjim zubima.

\section{Zahvala}

Velika hvala Hrvatskoj zakladi za znanost za financiranje projekta br.1218. pod nazivom Definiranje moguínosti uporabe minidentalnih implantata (MDI) i njihovi rezultati u istraživanjima in vitro i u kliničkim prospektivnim istraživanjima.

\section{Sukob interesa}

Autori nisu bili u sukobu interesa. 


\section{Sažetak}

Svrha: Željelo se procijeniti žvačnu funkciju i kvalitetu života ovisnu o oralnom zdravlju (OHRQoL) pacijentima starije dobi nakon triju različitih vrsta protetičke terapije u donjoj čeljusti - korištenja djelomičnih proteza dugačkih sedala (skupina PP-DP), potpunih proteza (skupina PP) ili potpunih pokrovnih proteza retiniranih na minidentalnim implantatima (skupina PP-MDI). Na početku terapije svi su pacijenti imali pomične samo donje prednje zube (1 mm ili >), a stražnja regija donje čeljusti bila je bezuba. Pacijenti su bili potpuno bezubi u gornjoj čeljusti. Nakon terapije svi su pozvani na kontrolni pregled i to tri mjeseca nakon protetičke rehabilitacije (razdoblje prilagodbe) i zatim poslije dvije godine. Materijali i metode: $U$ istraživanju je sudjelovalo ukupno 176 pacijenata (skupina PP $-n$ $=68$; skupina PP-DP $-n=58$; skupina PP-MDI $-n=50$ ). Žvačna funkcija procijenjena je s pomoću upitnika žvačne funkcije (CFQ), a OHRQoL upitnikom OHIP 14. Upitnike su pacijenti ispunjavali prije terapije, tri mjeseca nakon terapije (završena prilagodba) i dvije godine nakon terapije. Rezultati: OHRQoL i žvačna funkcija značajno su se poboljšali nakon terapije u svim trima skupinama pacijenata $(p<0,01)$. Najveće poboljšanje žvačne funkcije ustanovljeno je u skupini PP-MDI. Nakon terapije OHRQoL je bio značajno bolji u skupini PP-MDI u odnosu prema skupini PP $(p<0,01)$. Nakon dvije godine žvačna funkcija u skupini PP-MDI još se dodatno značajno poboljšala, a pogoršanje je utvrđeno u skupinama PP i PP-DP $(p<0,01)$. Isti rezultati zabilježeni su i za OHRQoL. Najveći broj reparatura proteza i dodatnih prilagodbi obavljen je u skupini PP-DP. Zaključak: Uz ograničenja ovog istraživanja, protetička rehabilitacija pokrovnim protezama koje su retinirane minidentalnim implantatima može se smatrati boljom terapijskom opcijom, uz trajno poboljšanje OHRQoL-a i žvačne funkcije, u odnosu prema terapiji s donjim potpunim protezama ili donjim djelomičnim protezama na preostalim pomičnim prednjim zubima.
Zaprimljen: 10. studeni 2018 Prihvaćen: 1. veljače 2019.

Adresa za dopisivanje Prof.dr.sc. Asja Čelebić Sveučilište u Zagrebu Stomatološki fakultet Zavod za mobilnu protetiku Gundulićeva 5, 10000 Zagreb tel: 14802111

faks: 14802159 celebic@sfzg.hr

Ključne riječi

zubne proteze; donja čeljust; zadovoljstvo bolesnika; žvakanje; dijagnostička samoprocjena; gerontostomatologija

\section{References}

1. Persic S, Celebic A. Influence of different prosthodontic rehabilitation options on oral health-related quality of life, orofacial esthetics and chewing function based on patient-reported outcomes. Qual Life Res. 2015 Apr;24(4):919-26.

2. Persic S, Celic R, Vojvodic D, Petricevic N, Kranjcic J, Zlataric DK et al. Oral Health-Related Quality of Life in Different Types of Mandibular Implant Overdentures in Function Longer Than 3 Years. Int J Prosthodont. 2016 Jan-Feb;29(1):28-30.

3. Zitzmann NU, Marinello CP. A review of clinical and technical considerations for fixed and removable implant prostheses in the edentulous mandible. Int J Prosthodont. 2002 JanFeb;15(1):65-72.

4. Petricevic N, Celebic A, Rener-Sitar K. A 3-year longitudinal study of quality-of-life outcomes of elderly patients with implant-and tooth-supported fixed partial dentures in posterior dental regions. Gerodontology. 2012 Jun;29(2):e956-63.

5. Cordaro L, di Torresanto VM, Petricevic N, Jornet PR, Torsello F. Single unit attachments improve peri-implant soft tissue conditions in mandibular overdentures supported by four implants. Clin Oral Implants Res. 2013 May;24(5):536-42.

6. Thomason IM, Kelly SA, Bendkowski A, Ellis IS. Two implant retained overdentures--a review of the literature supporting the McGill and York consensus statements. J Dent. 2012 Jan;40(1):22-34.

7. Feine JS, Carlsson GE, Awad MA, Chehade A, Duncan WJ, Gizani $\mathrm{S}$, et al. The McGill consensus statement on overdentures. Mandibular two-implant overdentures as first choice standard of care for edentulous patients. Int J Oral Maxillofac Implants. 2002 JulAug;17(4):601-2.

8. Srivastava A, Feine JS, Esfandiari S. Are people who still have their natural teeth willing to pay for mandibular two-implant overdentures? J Investig Clin Dent. 2014 May;5(2):117-24.

9. Bassi F, Mantecchini G, Carossa S, Preti G. Oral conditions and aptitude to receive implants in patients with removable partial dentures: a cross-sectional study. part I. oral conditions. J Oral Rehabil. 1996 Jan;23(1):50-4.

10. Bassi F, Schierano G, Lorenzetti M, Preti G. Oral conditions and aptitude to receive implants in patients with removable partial denture: a cross-sectional study. Part II Aptitude. J Oral Rehabil. 1996 Mar;23(3):175-8.

11. Gómez-de Diego R, Mang-de la Rosa Mdel R, Romero-Pérez MJ, Cutando-Soriano A, López-Valverde-Centeno A. Indications and contraindications of dental implants in medically compromised patients: update. Med Oral Patol Oral Cir Bucal. 2014 Sep 1;19(5):e483-9.

12. de Souza RF, Ribeiro AB, Della Vecchia MP, Costa L, Cunha TR, Reis AC, et al. Mini vs. Standard Implants for Mandibular Overdentures: A Randomized Trial. J Dent Res. 2015 Oct;94(10):1376-84.

13. ELsyad MA. Patient satisfaction and prosthetic aspects with miniimplants retained mandibular overdentures. A 5-year prospective study. Clin Oral Implants Res. 2016 Jul;27(7):926-33.
14. Schwindling FS, Schwindling FP. Mini dental implants retaining mandibular overdentures: A dental practice-based retrospective analysis. J Prosthodont Res. 2016 Jul;60(3):193-8.

15. Maryod WH, Ali SM, Shawky AF. Immediate versus early loading of mini-implants supporting mandibular overdentures: a preliminary 3-year clinical outcome report. - Early loading of MIs supporting a mandibular overdenture appears to be preferable to immediate loading. Int J Prosthodont. 2014;27:553-560.

16. Preoteasa E, Imre M, Preoteasa CT. A 3-year follow-up study of overdentures retained by mini-dental implants. Int J Oral Maxillofac Implants. 2014 Sep-Oct;29(5):1170-6

17. Scepanovic M, Todorovic A, Markovic A, Patrnogic V, Milicic B, Moufti AM, et al. Immediately loaded mini dental implants as overdenture retainers: 1 -Year cohort study of implant stability and peri-implant marginal bone level. Ann Anat. 2015 May;199:85-91.

18. Mundt T, Schwahn C, Biffar R, Heinemann F. Changes in Bone Levels Around Mini-Implants in Edentulous Arches. Int J Oral Maxillofac Implants. 2015 Sep-Oct;30(5):1149-55.

19. Mundt T, Schwahn C, Stark T, Biffar R. Clinical response of edentulous people treated with mini dental implants in nine dental practices. Gerodontology. 2015 Sep;32(3):179-87.

20. Müller F, Duvernay E, Loup A, Vazquez L, Herrmann FR, Schimmel M. Implant-supported mandibular overdentures in very old adults: a randomized controlled trial. J Dent Res. 2013;92(suppl 12):154S-160S.

21. Scepanovic M, Calvo-Guirado JL, Markovic A, Delgardo-Ruiz R, Todorovic A, Milicic B, et al. A 1-year prospective cohort study on mandibular overdentures retained by mini dental implants. Eur J Oral Implantol. 2012 Winter;5(4):367-79.

22. Flanagan D. Screwless fixed detachable partial overdenture treatment for atrophic partial edentulism of the anterior maxilla. J Oral Implantol. 2008;34(4):230-5.

23. Persic S, Palac A, Vojvodic D, Celebic A. Initial effects of a treatment by fixed partial dentures supported by mini dental implants from a patient's point of view. Coll Antropol. 2014;38:275-278.

24. Disha V, Celebic A, Rener-Sitar K, Kovacic I, Filipovic Zore I, Persic S. Mini Dental Implant-Retained Removable Partial Dentures: Treatment Effect Size and 6-Months Follow-up. Acta Stom Croat. 2018;53(3):184-192

25. Kovacic I, Persic S, Kranjcic J, Lesic N, Celebic A. Rehabilitation of an Extremely Resorbed Edentulous Mandible by Short and Narrow Dental Implants. Case Rep Dent. 2018 Dec 20;2018:7597851.

26. Kovacic I, Persic S, Kranjcic J, Disha V, Rener-Sitar K, Celebic A. Short-term Postoperative Pain and Swelling Associated with Mini and Standard-Size Implants in the Same Patients. Int J Prosthodont. 2018 Feb 15.

27. ELsyad MA, Ghoneem NE, El-Sharkawy H. Marginal bone loss around unsplinted mini-implants supporting maxillary overdentures: a preliminary comparative study between partial and full palatal coverage. Quintessence Int. 2013 Jan;44(1):45-52. 
28. Mundt T, Al Jaghsi A, Schwahn B, Hilgert J, Lucas C, Biffar R, et al. Immediate versus delayed loading of strategic mini dental implants for the stabilization of partial removable dental prostheses: a patient cluster randomized, parallel-group 3-year trial. BMC Oral Health 2017;17(1):30.

29. Miller PD Jr. A classification of marginal tissue recession. Int J Perio Rest Dent. 1985;5:9-13.

30. Miller PD Jr, McEntire ML, Marlow NM, Gellin RG. An evidencedbased scoring index to determine the periodontal prognosis on molars. J Periodontol. 2014 Sep;85(9):1158.

31. Rener-Sitar K, Petricevic N, Celebic A, Marion L. Psychometric properties of Croatian and Slovenian short form of oral health impact profile questionnaires. Croat Med J. 2008 Aug;49(4):536-44.

32. Persic S, Palac A, Bunjevac T, Celebic A. Development of a new chewing function questionnaire (CFQ) for assessment of a selfperceived chewing function. Community Dent Oral Epidemiol. 2013 Dec;41(6):565-73.

33. Waller N, John MT, Feuerstahler L, Baba K, Larsson P, Persic S, et al. A 7-day recall period for a clinical application of the oral health impact profile questionnaire. Clin Oral Investig. 2016 Jan;20(1):91-9.

34. Froum SJ, Rosen PS. A proposed classification for peri-implantitis. Int J Periodontics Restorative Dent. 2012 Oct;32(5):533-40.

35. Pozzi A, Tallarico M, Moy PK. Four-implant overdenture fully supported by a CAD/CAM titanium bar: A single-cohort prospective 1-year preliminary study. J Prosthet Dent. 2016 Oct;116(4):516523.

36. Persic S, Strujic S, Strajnic LJ, Ibrahimagic-Seper L, Selimovic E, Celebic A. Self-perceived esthetics, chewing function and oral health-related quality of life in patients treated with new removable dentures. Stoma Edu J. 2016;3:92-97.

37. Persic S, Kranjcic J, Pavicic DK, Mikic VL, Celebic A. Treatment Outcomes Based on Patients' Self-Reported Measures after Receiving New Clasp or Precision Attachment-Retained Removable Partial Dentures. J Prosthodont. 2017 Feb;26(2):115-122.

38. Caplan DJ, Weintraub JA. The oral health burden in the United States: a summary of recent epidemiologic studies. J Dent Educ. 1993 Dec;57(12):853-62.

39. Jordan RA, Bodechtel C, Hertrampf K, Hoffmann T, Kocher T, Nitschke I, et al. Surveillance Investigators' Group. The Fifth German Oral Health Study (Fünfte Deutsche Mundgesundheitsstud ie, DMS V) - rationale, design, and methods. BMC Oral Health. 2014;14:161.

40. Celebic A, Knezovic-Zlataric D. A comparison of patient's satisfaction between complete and partial removable denture wearers. Dent. 2003 Sep;31(7):445-51.

41. Celebic A, Knezovic-Zlataric D, Papic M, Carek V, Baucic I, Stipetic J. Factors related to patient satisfaction with complete denture therapy. J Gerontol A Biol Sci Med Sci. 2003 Oct;58(10):M948-53.

42. Zlatarić DK, Celebić A. Factors related to patients' general satisfaction with removable partial dentures: a stepwise multiple regression analysis. Int I Prosthodont. 2008 Jan-Feb;21(1):86-8.

43. Aimaijiang Y, Otomaru T, Taniguchi H. Relationships between perceived chewing ability, objective masticatory function and oral health-related quality of life in mandibulectomy or glossectomy patients with a dento-maxillary prosthesis. J Prosthodont Res. 2016 Apr;60(2):92-7.
44. John MT, Reißmann DR, Feuerstahler L, Waller N, Baba K, Larsson P, et al. Factor analyses of the Oral Health Impact Profile overview and studied population. J Prosthodont Res. 2014 Jan;58(1):26-34.

45. John MT, Reissmann DR, Feuerstahler L, Waller N, Baba K, Larsson $\mathrm{P}$, et al. Exploratory factor analysis of the Oral Health Impact Profile. J Oral Rehabil. 2014 Sep;41(9):635-43.

46. John MT, Feuerstahler L, Waller N, Baba K, Larsson P, Celebic A, et al. Confirmatory factor analysis of the Oral Health Impact Profile. J Oral Rehabil. 2014 Sep;41(9):644-52.

47. John MT, Rener-Sitar K, Baba K, Celebic A, Larsson P, Szabo G, et al. Patterns of impaired oral health-related quality of life dimensions. J Oral Rehabil. 2016 Jul;43(7):519-27.

48. Reissmann DR, John MT, Feuerstahler L, Baba K, Szabó G, Celebic $A$, et al. Longitudinal measurement invariance in prospective oral health-related quality of life assessment. Health Qual Life Outcomes. 2016;14:88.

49. Allen F, Locker D. A modified short version of the oral health impact profile for assessing health-related quality of life in edentulous adults. Int J Prosthodont. 2002;15:446-450.

50. Palac A, Bitanga P, Capkun V, Kovacic I. Association of cephalometric changes after 5 years of complete dentures wearing and oral health-related quality-of-life. Acta Odontol Scand. 2013;71:449-456.

51. Kovacic I, Knezovic Zlataric D, Celebic A. Residual ridge atrophy in complete denture wearers and relationship with densitometric values of a cervical spine: a hierarchical regression analysis. Gerodontology. 2012;29:e935-e947.

52. Kovacic I, Celebic A, Zlataric DK, Petricevic N, Bukovic D, Bitanga $P$, et al. Decreasing of residual alveolar ridge height in complete denture wearers. A five year follow up study. Coll Antropol. 2010;34:1051-1056.

53. Yoshida T, Masaki C, Komai H, Misumi S, Mukaibo T, Kondo Y, et al. Changes in oral health-related quality of life during implant treatment in partially edentulous patients: A prospective study. J Prosthodont Res. 2016 Oct;60(4):258-264.

54. Leung DY, Leung AY, Chi I. Factors associated with chewing problems and oral dryness among older Chinese people in Hong Kong. Gerodontology. 2016;33:106-115.

55. Kossioni AE, Kossionis GE, Polychronopoulou A. Oral health status of elderly hospitalised psychiatric patients. Gerodontology. 2012;29:272-283.

56. Müller F. Interventions for edentate elders--what is the evidence? Gerodontology. 2014;31Suppl 1:44-51.

57. Zlataric DK, Celebic A, Valentic-Peruzovic M. The effect of removable partial dentures on periodontal health of abutment and nonabutment teeth. J Periodontol. 2002 Feb;73(2):137-44.

58. Reissmann DR. Alignment of oral health-related with healthrelated quality of life assessment. J Prosthodont Res. 2016 Apr;60(2):69-71.

59. Gosavi SS, Ghanchi M, Malik SA, Sanyal P. A survey of complete denture patients experiencing difficulties with their prostheses. J Contemp Dent Pract. 2013;14:524-527.

60. John MT, Reissmann DR, Celebic A, Baba K, Kende D, Larsson P, et al. Integration of oral health-related quality of life instruments. J Dent. 2016 Oct;53:38-43.

61. Borgnakke WS. Does Treatment of Periodontal Disease Influence Systemic Disease? Dent Clin North Am. 2015 Oct;59(4):885-917. 